Kamrin, A. A., and Singer, M. (1959). F. Morph., 104, 415.

Merrington, W. R., and Nathan, P. (1949). f. Neurol. Neurosurg. Psychiat., 12, 1.

Ommaya, A. K. (1963). Personal communication. Bethesda.

Pudenz, R. H., and Shelden, C. H. (1946). f. Neurosurg., 3, 487.

Russell, W. R. (1932). Brain, 55, 549.

- (1959). Brain: Memory: Learning. Clarendon Press, Oxford.

Scott, D., and Liu, Chan-Nao (1963). Exp. Neurol., 8, 279.

Seddon, H. J. (1954). Editor of Peripheral Nerve Injuries. M.R.C. Spec. Rep. Ser. Med. Res. Coun. (Lond.), No. 282. H.M.S.O., London.
Sellier, K., and Unterharnscheidt, F. (1963). Mechanik und Pathomorphologie der Hirnshdden nach stumpfer Gewalteinwirkung auf den Schädel. Springer-Verlag, Berlin.

Strich, S. J. (1956). F. Neurol. Neurosurg. Psychiat., 19, 163.

Surgery in World War II, United States Army (1959). Vol. 2, Neurosurgery. Washington.

Tönnis, D. (1963). Ruckenmarkstrauma und Mangeldurchblutung. Barth-Verlag, Leipzig.

Trotter, W. (1924). Lancet, 1, 935

Unterharnscheidt, F. (1963). Die gedeckten Schäden des Gehirns. Springer-Verlag, Berlin.

\title{
Daily Haemodialysis in "Hypercatabolic" Acute Renal Failure
}

\author{
H. SILVA,* M.D. ; J. POMEROY,* M.D. ; A. I. RAE,* M.B., M.R.C.P. ; S. M. ROSEN, $\dagger$ M.B., M.R.C.P. ; \\ STANLEY SHALDON, $\ddagger$ M.A., M.D., M.R.C.P.
}

Brit. med. F., 1964, 2, 407-410

The value of early and frequent haemodialysis in the management of acute "hypercatabolic" renal failure (daily plasmaurea increment exceeding $60 \mathrm{mg} . / 100 \mathrm{ml}$.) is well established (Parsons et al., 1961).

The problem of increasing the number of haemodialyses for the individual patient with acute renal failure has been solved regarding the requirement for repeated access to the vascular bed by the use of a silastic-teflon arteriovenous shunt (Quinton et al., 1962) or permanent twin femoral venous catheterization (Shaldon et al., 1963). However, logistic and economic problems concerning cost, staff, equipment, and blood requirements still exist. Although low-flow refrigerated haemodialysis with a modified Kiil dialyser (Kiil, 1960 ; Cole et al., 1962) is economic in terms of physician-time, skilled technicians are required to sterilize and assemble the dialyser. The modified Kolff twin-coil dialyser (Shaldon et al., 1964) retains $70 \%$ efficiency of the original model and maintains adequate control of uraemia in the absence of renal function using four- to six-hour periods of dialysis.

We report here our experience with daily haemodialysis in eight patients with acute " hypercatabolic" renal failure, using the modified Kolff twin-coil dialyser with refrigeration, regional heparinization, coil re-utilization, and femoral venous catheter prostheses (Shaldon et al., 1964).

\section{Material and Management}

Eight patients, four males and four females, aged from 15 to 70 years, were treated (Table I). Renal failure was due to accidental trauma (1 patient), surgical trauma (5 patients), ethylene glycol ingestion (1 patient), and septic abortion and Gram-negative septicaemia ( 1 patient). For inclusion in the series as "hypercatabolic" renal failure the initial daily increment of plasma urea had to exceed $80 \mathrm{mg} . / 100 \mathrm{ml}$.

Immediately after confirmation of the diagnosis of acute renal failure, twin Teflon catheters were inserted percutaneously into the femoral vein under local anaesthesia (Shaldon et al., 1964). Most of the patients were referred late with established uraemic symptoms (average admission plasma urea $340 \mathrm{mg} . / 100 \mathrm{ml}$.) and consequently the initial dialysis was invariably performed as an emergency and always within six hours of admission.

* Research Fellow, Department of Medicine, Royal Free Hospital, London.

† Medical Registrar, Department of Medicine, Royal Free Hospital, London.

‡Lecturer in Medicine, Department of Medicine, Royal Free Hospital, London.
Control of uraemia was achieved initially by short dialyses (one and a half to three hours) at intervals of 12 to 16 hours using $2 \%$ dextrose in the rinsing-fluid to avoid a "disequilibrium syndrome" (Kennedy et al., 1963a ; Rosen et al., 1964) occasioned by too rapid a drop in plasma-urea level in a patient presenting with a plasma urea greater than $300 \mathrm{mg} . / 100 \mathrm{ml}$. In spite of this policy, three patients developed respiratory difficulty with a disequilibrium syndrome and required tracheostomy, and one of them needed positive-pressure ventilation. After the initial series of short haemodialyses, patients were managed on a daily regimen with an average of five hours' dialysis.

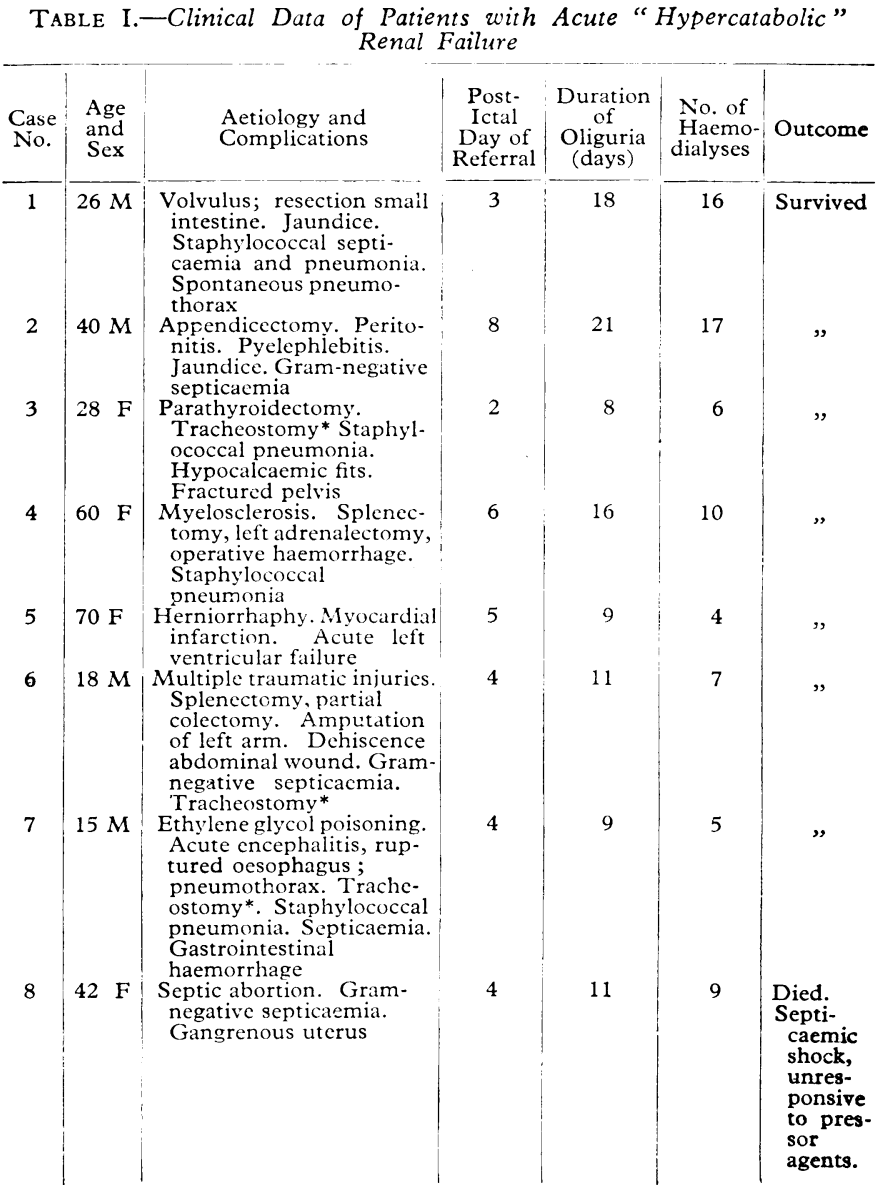

* Respiratory distress treated with tracheostomy \pm positive-pressure ventilation. 
The aim of dialysis was to keep the patient free of uraemic symptoms, while permitting an intake of $60 \mathrm{~g}$. of protein, 2,500 calories, and $1,500 \mathrm{ml}$. of fluid. To achieve this end it was necessary to remove by ultrafiltration 1,000 to $1,500 \mathrm{ml}$. of fluid daily and to prevent the plasma urea from rising above 150 mg. $/ 100 \mathrm{ml}$.

All patients were dialysed, using the modified twin-coil dialyser with regional heparinization. They all received watersoluble-vitamin replacements at the end of each dialysis. As soon as the individual patient was free from uraemic symptoms the entire procedure was run by trained nursing staff without requiring a physician in the dialysing room at any time. It was thus possible to treat three or four patients in any one 24-hour period. Daily haemodialysis was continued until the onset of the late diuretic phase (Loughbridge et al., 1960).

\section{Clinical Results}

Uraemic symptoms were not present in any patient after initial control of the uraemia, which usually required two to three days to achieve because of the late time of referral. The symptoms of thirst, nausea, anorexia, vomiting, and drowsiness disappeared and the patients were able to enjoy their diet and

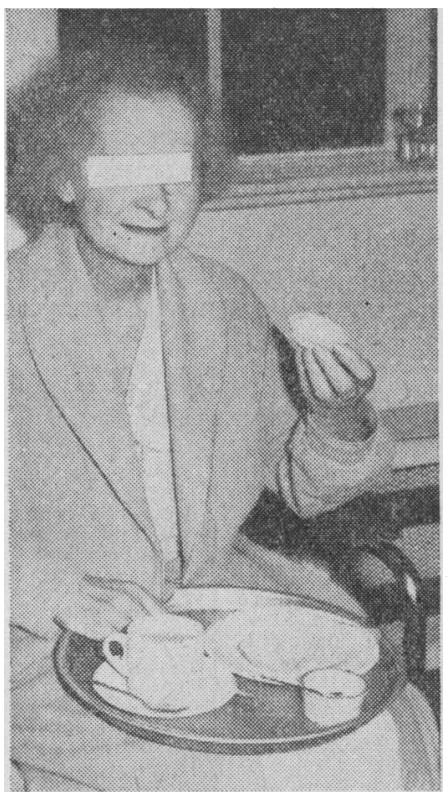

FIG. 1.-Case 4. Patient eating her afternoon tea one hour after finishing her third daily haemodialysis and nine days after the onset of acute " hypercatabolic" renal fallure due to massive haemorrhage following splenectomy, and subsequently complicated by staphylococcal pneumonia.

were encouraged to eat foods of their own preference. One patient (Case 2) ate eggs, sausages, and chips with a glass of beer at his first meal, as soon as his paralytic ileus had remitted, although he remained oliguric for a further 15 days. Loss of weight was difficult to assess as many patients were overhydrated at the start of treatment, but loss of flesh did not occur with control of the uraemic syndrome and the relatively free dietary intake. Wound-healing progressed at normal rates and control of infection was not affected by the absence of renal function. Because of the daily haemodialysis schedule, antibiotics normally dependent upon renal function for excretion were used when indicated, without resultant high or toxic blood levels. Gastro-intestinal haemorrhage was a prominent complication in cases 4 and 7 , but it subsided with control of the uraemia during daily haemodialysis. However, the anaemia associated with acute renal failure was not significantly affected by daily haemodialysis, and all patients required periodic blood transfusions to maintain a haematocrit of $25 \%$. Nevertheless the average blood requirement for the whole oliguric period, including blood used for initial priming of the twin-coil dialyser, was only $3,000 \mathrm{ml}$.

Early ambulation was encouraged, and patients were allowed out of bed as soon as the initiating cause of renal failure permitted (Fig. 1). Occasional oozing from the groin puncture sites occurred during the first two or three days after introduction of the catheters, but this subsided with bed rest and gentle pressure. It was not necessary to change the catheters in any of the patients. Skin sepsis at the puncture site occurred in one patient (Case 8), but this cleared with local antibiotic treatment. Catheters were removed 48 to 72 hours after the last dáily haemodialysis. At the time of removal firm pressure was applied to the puncture sites for 15 minutes. Uneventful healing occurred.

Seven of the patients recovered and left hospital with normal plasma urea levels one to two months after onset of renal failure.

\section{Case 1}

\section{Jaundice and Acute Renal Failure, due to Volvulus and Resection of the Small Intestine-Survived}

A previously healthy 26-year-old male electrician developed acute renal failure after án emergency laparotomy for volvulus of the small bowel which necessitated resection of the major part of a gangrenous small intestine with jejuno-caecal anastomosis. He was referred three days after the onset of oliguria when he was already markedly uraemic and deeply jaundiced, with drowsiness, vomiting, increased muscle tone, and a flapping tremor. Blood-pressure was $110 / 70$ and there was no evidence of oedema.

Investigations on Admission.-Plasma urea $345 \mathrm{mg} . / 100 \mathrm{ml}$., plasma creatinine $8.5 \mathrm{mg} . / 100 \mathrm{ml}$., plasma uric acid $12.0 \mathrm{mg} . /$ $100 \mathrm{ml}$., plasma inorganic phosphorus $12.6 \mathrm{mg} .100 \mathrm{ml}$., plasma

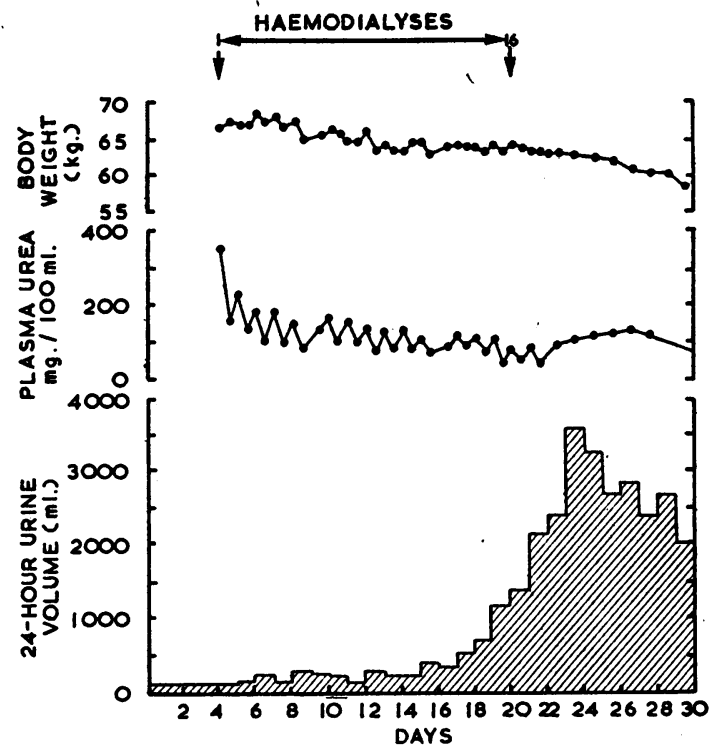

Frg. 2.-Case 1. Progress of patient treated by daily haemodialysis (see text for clinical details). During the first week the rise in plasma urea between dialyses was greater than during the second week, although the patient was then eating more protein, suggesting reduction in was then eating more protein, suggesting a reduction in endogenous protein catabolism as a result of consrol of
uraemia and infection. The onset of the diuretic phase was not delayed by daily haemodialysis and the urine volumes increased each day in the diuretc phase in spite of lowering the plasma urea by haemodialysis.

sodium $123 \mathrm{mEq} / 1$. , plasma potassium $6.8 \mathrm{mEq} / 1$., plasma bicarbonate $14.2 \mathrm{mEq} / \mathrm{l}$., P.C.V. $17 \%$, serum bilirubin $26 \mathrm{mg}$. $100 \mathrm{ml}$., alkaline phosphatase 15 K.A. units, serum glutamic oxaloacetic transaminase 250 units $/ 1$. 
The uraemia was controlled by three short haemodialyses in the first 48 hours and the patient then received 13 further dialyses over the next 16 days (Fig. 2). The average plasma-urea pre-dialysis was $130 \mathrm{mg} . / 100 \mathrm{ml}$. and $30 \mathrm{~g}$. of urea was removed per dialysis. The patient was taking a $60-\mathrm{g}$. protein diet within 72 hours of admission and the abdominal wound healed by first intention. However, blood culture on admission yielded a coagulase-positive staphylococcus and the initial progress was complicated by a staphylococcal septicaemia which responded to intravenous cloxacillin. Further complications in the early oliguric period included massive diarrhoea with 7 to 8 litres of fluid stools per day, and a left spontaneous pneumothorax, which required intercostal drainage. In spite of these complications, the patient improved steadily during the oliguric phase, and by the time that dialytic treatment was terminated he was already fully ambulant.

Liver biopsy in the convalescent period showed evidence of healing centrizonal necrosis of the liver, and renal biopsy confirmed the diagnosis of a recovering tubular necrosis.

He left hospital two months after admission with a normal blood urea and creatinine clearance but with a mild steatorrhoea associated with the massive resection of the small intestine.

Comment.-This patient with jaundice and acute renal failure required 16 haemodialyses before his own renal function had recovered sufficiently to prevent the development of uraemic symptoms. In spite of complications, including a staphylococcal septicaemia, fulminating diarrhoea, and a spontaneous pneumothorax, he made an uneventful recovery.

\section{Case 8}

\section{Septic Abortions, Gram-negative Septicaemia, Gangrenous Uterus, Acute Renal Failure: Died}

A 42-year-old housewife was referred five days after the onset of oliguric acute renal failure, following a septic abortion. At the time of referral she was already clinically uraemic, with disorientation, drowsiness, vomiting, and a flapping tremor. She was overhydrated, with oedema of the ankles and elevated jugular venous pressure. The uterus was enlarged and tender and there was an offensive vaginal discharge.

Investigations on Admission.-Plasma urea $320 \mathrm{mg} . / 100 \mathrm{ml}$., plasma creatinine $9 \mathrm{mg} . / 100 \mathrm{ml}$., plasma uric acid $16 \mathrm{mg} . / 100 \mathrm{ml}$., plasma inorganic phosphorus $12 \mathrm{mg} . / 100 \mathrm{ml}$., plasma sodium $120 \mathrm{mEq} / 1$., plasma potassium $6.7 \mathrm{mEq} / 1$, plasma bicarbonate $15 \mathrm{mEq} / \mathrm{l}$. Blood culture grew Proteus morganii, and vaginal swab Pr. morganii.

The patient was treated with four short haemodialyses in the first 48 hours and became free of uraemic symptoms. In the next week she was well enough to indulge in occupational therapy and was eating her full diet. However, her progress was intermittently complicated by repeated episodes of hyperpyrexia and hypotension associated with repeatedly positive blood cultures of Pr. morganii. In spite of intravenous kanamycin she died one week after admission, following nine haemodialyses, with progressive Gram-negative septicaemic shock. Hysterectomy was to have been performed on the day she died. She was still oliguric at the time of death.

Post-mortem examination revealed the presence of a recovering acute tubular necrosis and a gangrenous uterus which grew $\mathrm{Pr}$. morganii on culture.

Comment.-Although the uraemic syndrome of this patient was adequately controlled by daily haemodialysis she died from the effects of progressive Gram-negative septicaemia, which might have been controlled had hysterectomy been performed at an earlier date.

\section{Dialysis Data}

Daily haemodialysis did not prolong the oliguric period, which averaged 13 days and represented overall 103 patientdays. However, haemodialysis therapy was given on only 66 patient-days because of delay in referral. During this time 13 disposable twin-coil dialysers were reused to perform 74 haemodialyses, averaging 9 dialyses (range 4-17) per patient.
The average reuse of the twin-coil unit was 6 times (range 4-10) and average total duration of dialysis per dialyser was 30 hours (range 20-50 hours), with a mean value of 5 hours per individual haemodialysis.

The mean blood-flow rate during dialysis was $200 \mathrm{ml}$./minute (range 170-350 ml./minute) measured with an electromagnetic flowmeter ${ }^{1}$ and urea dialysance averaged $120 \mathrm{ml} . /$ minute. There was no significant reduction of urea dialysance with reuse of the same twin-coil dialyser on as many as 10 occasions with a total dialysing time of 50 hours.

Complications were minimal with the reusable-coil technique. On two occasions (3\%) clotting in the circuit resulted in loss of the coil unit. Leakage from the coil occurred on four occasions $(6 \%)$. Febrile reactions were infrequent but occurred more commonly after reuse of the same coil unit for more than 10 days. For this reason the coil units were not reused after 10 days.

The mean referral plasma urea was $340 \mathrm{mg} . / 100 \mathrm{ml}$. Each patient required one to three short dialyses in the first 12 to 48 hours to establish clinical and biochemical control of uraemia. After this initial period biochemical control was standardized by four to six-hour daily dialysis periods. The average pre-dialysis plasma urea was $154 \pm 223 \mathrm{mg} . / 100 \mathrm{ml}$. and post-dialysis was $79 \pm 14 \mathrm{mg} . / 100 \mathrm{ml}$. (Table II, Fig. 2). Thus the average daily rise in plasma urea was $75 \mathrm{mg} . / 100 \mathrm{ml}$. after control of uraemia. This rise represents the mean of two separate rates of daily plasma increment. In the first few days the daily plasma-urea increment often exceeded $100 \mathrm{mg}$./ $100 \mathrm{ml}$. However, as hypercatabolism became less marked with wound-healing and resolution of infection the daily plasma-urea increment decreased to $30 \mathrm{mg}$. $/ 100 \mathrm{ml}$. During the hypercatabolic phase, urea removal averaged $30 \mathrm{~g}$. but subsequently dropped to $20 \mathrm{~g}$. per haemodialysis.

TABLE II.-Biochemical Control of Uraemia During Daily Haemodialysis

\begin{tabular}{|c|c|c|c|}
\hline \multicolumn{2}{|l|}{ Plasma Constituents } & Pre-Dialysis & Post-Dialysis \\
\hline 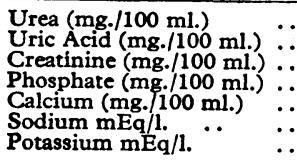 & 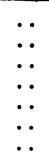 & 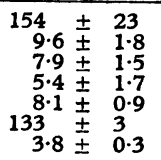 & $\begin{array}{rll}79 & \pm & 14 \\
6.8 \pm \pm & 1.5 \\
5.6 \pm \pm & 0.6 \\
4.3 \pm & 1.2 \\
8.9 & \pm & 0.7 \\
133 & \pm \\
3.6 & 2 \\
3.6 & 0.3\end{array}$ \\
\hline
\end{tabular}

$\pm=1$ standard deviation.

Creatinine and uric acid were not removed as efficiently as urea. Pre-dialysis plasma-creatinine levels averaged $7.9+1.5$ mg. $/ 100 \mathrm{ml}$. and $5.6 \pm 0.6 \mathrm{mg} . / 100 \mathrm{ml}$. post-dialysis. Predialysis plasma-uric-acid levels averaged $9.6 \pm 1.8 \mathrm{mg} . / 100 \mathrm{ml}$. and $6.8 \pm 1.5 \mathrm{mg} . / 100 \mathrm{ml}$. post-dialysis. Plasma-calcium levels rose slightly during daily haemodialysis from $8.1 \pm 0.9 \mathrm{mg}$./ $100 \mathrm{ml}$. to $8.9 \pm 0.7 \mathrm{mg} . / 100 \mathrm{ml}$. This was due to the high calcium content of local tap-water $(10 \mathrm{mg} . / 100 \mathrm{ml}$.), and no calcium was added to the rinsing-fluid used for dialysis. Plasma-sodium levels did not alter during daily haemodialysis and remained at $130-135 \mathrm{mEq} / \mathrm{l}$. after correction of initial hyponatraemia. Plasma-potassium levels were kept below $4 \mathrm{mEq} / 1$. by daily haemodialysis. Ion-exchange resins were not required in spite of a dietary potassium intake of 40-60 mEq/ day. Similarly, plasma-bicarbonate levels did not fall below $19 \mathrm{mEq} / 1$. after initial correction of the metabolic acidosis.

\section{Discussion}

Acute " hypercatabolic" renal failure used to have a survival rate of $10-20 \%$ when conservative treatment with occasional haemodialysis was employed (Jackson et al., 1960 ; Shackman et al., 1960). More recently significant improvement in survival rates of $50-60 \%$ was reported with earlier and more frequent

\footnotetext{
Electromagnetic flowmeter obtainable from Medelec Ltd., Woking,

$\pm=1$ standard deviation.
} 
haemodialysis (Parsons et al., 1961 ; Kennedy et al., 1963b). However, even higher survival rates of $75-80 \%$ have been reported when the uraemic syndrome was completely controlled by either daily haemodialysis (Teschan et al., 1960) or continuous haemodialysis during the hypercatabolic stage of the illness (Murray et al., 1961). The latter experience has been entirely confirmed by the present series. It is now evident that patients with acute "hypercatabolic" renal failure should not die unless the initiating injury proves fatal or the renal failure is due to renal cortical necrosis where insufficient renal function recovers to maintain life. The principle causes of death in acute " hypercatabolic" renal failure have been from sepsis or gastro-intestinal haemorrhage (Shackman et al., 1960). With daily haemodialysis, resolution of infection with appropriate antibiotic therapy should occur and gastrointestinal haemorrhage ceases with adequate control of uraemia.

The major problem remains one of late referral. When the plasma urea rises at over $100 \mathrm{mg}$. $/ 100 \mathrm{ml}$. daily, 24 to 48 hours' delay in instituting therapy may result in a "dialysis disequilibrium syndrome" during initial haemodialysis with death from cerebral or pulmonary oedema. The syndrome results from the rapid removal of urea from plasma, with a slower removal of urea from cerebrospinal fluid and subsequent transfer of water into the C.S.F. with rise in C.S.F. pressure (Kennedy et al., 1962 ; Gilliland and Hegstrom, 1963; Rosen et al., 1964). This syndrome is particularly likely to occur when dialysis is performed with a plasma urea of over $300 \mathrm{mg}$./ $100 \mathrm{ml}$. To avoid this syndrome, hypertonic dextrose $(2 \%)$ has been recommended for the rinsing-fluid, and, in addition, the plasma urea should not be lowered too rapidly. This can be achieved by short haemodialyses of one to two hours' duration for the first 24 to 48 hours, and the coil-reutilization technique is ideal for this purpose. Alternatively, the rinsing-fluid can be made up to contain a concentration of urea equalling $50 \%$ of the patient's pre-dialysis plasma urea (R. Hegstrom, personal communication). However, these problems would not arise if early referral to a dialysis centre was routine for patients with "hypercatabolic" renal failure, as the initial haemodialysis could then be performed with a plasma urea of less than $200 \mathrm{mg} . / 100 \mathrm{ml}$.

The fact that daily haemodialysis did not prolong the oliguric phase suggested that the onset of diuresis was not related to the height of the plasma urea. The volume of urinary output at the onset of diuresis was not predominantly solutedependent, as lowering of the plasma urea by haemodialysis at this stage did not reduce the urinary volume (Fig. 2).

Alternative methods of intensive control of acute uraemia have yielded equally promising results. Continuous peritoneal dialysis has produced comparable survival rates, but it has usually been necessary to control the uraemia initially with the use of a dialyser (Burns et al., 1962). The disadvantage of peritoneal dialysis has been the risk of peritonitis, and the patient is also restricted to bed and cannot indulge in early ambulation and occupational therapy. Furthermore, even with the availability of commercial sterile rinsing-fluids the cost of peritoneal dialysis is no less than daily haemodialysis with coil reutilization. Continuous low-flow pumpless haemodialysis using a Kiil dialyser (Cole et al., 1962) has yielded extremely promising results and is entirely a nursing-technician procedure. However, the patient-time required for treatment is prolonged and restricts rehabilitation during the oliguric period. In addition each patient requires his own dialyser for the duration of the "hypercatabolic" oliguric period, and this restricts the number of patients whom one unit could treat over the same period of time. As the commonest dialyser available is the Kolff twin-coil unit, the technique of coil reutilization would now permit daily haemodialysis to be performed in the treatment of acute " hypercatabolic" renal failure in most renal centres. Up to four patients can be treated in a 24-hour schedule, and it would be unusual for most renal units to have to exceed this requirement.

The free diet and early ambulation permitted by control of uraemia had a striking effect on patients' morale. There was no reluctance to submit to daily haemodialysis therapy for four to six hours. During the time of dialysis the patients were able to watch television, eat and drink, and there was no anxiety associated with the treatment. The free diet simplified the nursing and dietary management of these patients.

The cost of daily haemodialysis rarely exceeds the cost of conventional haemodialysis for acute "hypercatabolic" renal failure, as the number of coils used averaged less than two per patient.

The efficiency of the nursing staff running the haemodialysis improved considerably with the increase in the number of dialyses, and it was possible to allow the whole programme to be run by trained nursing staff once the patient was asymptomatic. Furthermore, with a regular dialysis commitment it was possible to justify the employment of nursing staff full-time in the renal unit, with considerable improvement in overall management.

\section{Summary}

Eight patients with acute "hypercatabolic" renal failure (daily plasma-urea increment exceeding $80 \mathrm{mg} . / 100 \mathrm{ml}$.) were treated by daily haemodialysis until the commencement of the established diuretic phase; seven patients survived. The technique of haemodialysis involved a modified twin-coil Kolff dialyser, run entirely by trained nursing staff. The twin coils were reused 4 to 10 times and 74 haemodialyses were performed with only 13 twin-coil units. Repeated access to the vascular system was obtained with indwelling femoral-venous catheters kept patent between dialysis with heparin-perfusion units.

We would like to thank Sister J. Oakley and the nursing staff of the renal unit. Without their intensive and enthusiastic support this form of therapy could not have been developed. In addition we wish to thank Messrs. Boehringer Ingelheim Ltd. and Messrs. Ciba Ltd. for financial support. Three of us were in receipt of fulltime grants: H. S. from the Royal Free Hospital, J.P. from the British Council, and A. I. R. from the Medical Research Council.

\section{REFERENCES}

Burns, R. O., Henderson, L. W., Hager, E. B., and Merrill, J. P. (1962). New Engl. 7. Med., 267, 1060 .

Cole, J. J., Quinton, W. E., Williams, C., Murray, J. S., and Sherris, J. C. (1962). Trans. Amer. Soc, art. intern. Org., 8, 209.

Gilliland, K. G., and Hegstrom, R. M. (1963). Ibid., 9, 44.

Jackson, R. C., Bunker, N. V. D., Elder, W. J., and Joekes, A. M. (1960). Brit. med. F., 2, 1909.

Kennedy, A. C., Linton, A. L., and Eaton, J. C. (1962). Lancet, 1, 410. Luke, R. G., and Renfrew, S. (1963a). Ibid., 1, 408.

- Luke, R. G., Linton, A. L., Eaton, J. C., and Gray, M. J. B. (1963b). Scot. med. 7., 8, 97.

Kiil, F. (1960). Acta chir. scand., Suppl. No. 253, p. 142

Kiil, F. (1960). Acta chir. scand., Suppl. No. 253, p. 142. (1960). Lancet, 1, 351 .

Murray, J. S., Hegstrom, R. M., Pendras, J. P., Burnell, J. M., and Scribner, B. H. (1961). Trans. Amer. Soc. art. intern. Org., 7, 94. Parsons, F. M., Hobson, S. M., Blagg, C. R., and McCracken, B. H. (1961). Lancet, 1, 129.

Quinton, W. E., Dillard, D. H., Cole, J. J., and Scribner, B. H. (1962). Trans. Amer. Soc. art. intern. Org., 8, 236.

Rosen, S. M., O'Connor, K. T., and Shaldon, S. (1964). Symposium on Acute Renal Failure. Blackwell, Oxford.

Shackman, R Milne, M. D., and Struthers, N. W. (1960). Brit. med. 7., 2, 1473 .

Shaldon, S., Rae, A. I., Rosen, S. M., Silva, H., and Oakley, J. (1963). Ibid., 1, 1716

Silva, H., and Rosen, S. M. (1964). Ibid., 2, 411.

Teschan, P. E., Baxter, C. R., O'Brien, T. F., Freyhof, J. N., and Hall, W. H. (1960). Ann. intern. Med., 53, 992. 